\title{
Correction to: A probabilistic investigation on the dynamic behaviour of pile foundations in homogeneous soils
}

\author{
Lucia Minnucci ${ }^{1}$. Michele Morici ${ }^{2}$. Sandro Carbonari ${ }^{1}$ (D) Francesca Dezi ${ }^{3}$. \\ Fabrizio Gara ${ }^{1} \cdot$ Graziano Leoni $^{2}$
}

Published online: 9 December 2021

(c) Springer Nature B.V. 2021

\section{Correction to: Bulletin of Earthquake Engineering https://doi.org/10.1007/s10518-021-01272-0}

Due to proofing error, author surnames were reversed and should correctly read as:

Lucia Minnucci, Michele Morici, Sandro Carbonari, Francesca Dezi, Fabrizio Gara, Graziano Leoni

Original article has been updated.

Publisher's Note Springer Nature remains neutral with regard to jurisdictional claims in published maps and institutional affiliations.

The original article can be found online at https://doi.org/10.1007/s10518-021-01272-0.

Sandro Carbonari

s.carbonari@univpm.it

1 Università Politecnica delle Marche, DICEA Via Brecce Bianche, 60131 Ancona, Italy

2 University of Camerino, SAAD Viale Della Rimembranza, 63100 Ascoli Piceno, Italy

3 University of San Marino, DESD Via Consiglio dei Sessanta, 99, 47891 Dogana, San Marino 